\title{
Fostering English vocabulary learning through gamification strategy. A preliminary study
}

\section{Fomentar del aprendizaje del vocabulario en inglés mediante la estrategia de gamificación. Un estudio preliminar}

1 Cristina del Rocío Jordán Buenaño https://orcid.org/0000-0003-1938-1379 Universidad Técnica de Ambato, Facultad de Ciencias Humanas y de la Educación, Carrera de Pedagogía de los idiomas Nacionales y Extranjeros. Ambato, Ecuador, cristinadjordanb@uta.edu.ec

2 Edgar Guadia Encalada Trujillo

https://orcid.org/0000-0001-8843-4804 Universidad Técnica de Ambato, Facultad de Ciencias Humanas y de la Educación, Carrera de Pedagogía de los idiomas Nacionales y Extranjeros Ambato, Ecuador, eg.encalada@uta.edu.ec

3 Sarah Jacqueline Iza Pazmiño iD https://orcid.org/0000-0002-8059-7868 Universidad Técnica de Ambato, Facultad de Ciencias Humanas y de la Educación, Carrera de Pedagogía de los idiomas Nacionales y Extranjeros. Ambato, Ecuador, sj.iza@uta.edu.ec

$4 \quad$ Sonnia Paulina Altamirano Carvajal https://orcid.org/0000-0003-0926-9252. Universidad Técnica de Ambato, Centro de Idiomas, Ambato, Ecuador, sonniapaltamiranoc@uta.edu.ec

\section{Artículo de Investigación Científica y Tecnológica}

Enviado: 24/12/2021

Revisado: 29/12/2021

Aceptado: 12/01/2022

Publicado:08/03/2023

DOI: https://doi.org/10.33262/concienciadigital.v6i1.4.1986

Cítese: $\quad$ Jordán Buenaño, C. del R., Encalada Trujillo, E. G., Iza Pazmiño, S. J., \& Altamirano Carvajal, S. P. (2023). Fostering English vocabulary learning through gamification strategy. A preliminary study . ConcienciaDigital, 6(1.4), 60-78. https://doi.org/10.33262/concienciadigital.v6i1.4.1986

CONCIENCIA DIGITAL, es una Revista Multidisciplinar, Trimestral, que se publicará en soporte electrónico tiene como misión contribuir a la formación de profesionales competentes con visión humanística y crítica que sean capaces de exponer sus resultados investigativos y científicos en la misma medida que se promueva mediante su intervención cambios positivos en la sociedad. https://concienciadigital.org La revista es editada por la Editorial Ciencia Digital (Editorial de prestigio registrada en la Cámara Ecuatoriana de Libro con No de Afiliación 663) www.celibro.org.ec 


\section{Palabras claves: \\ Estrategia de gamificación, idioma inglés, plataforma Duolingo, adquisición de vocabulario.}

\begin{abstract}
Resumen
Este estudio se realizó para establecer la efectividad de la estrategia de Gamificación en la adquisición de vocabulario en el idioma inglés en los estudiantes del primer semestre del Programa de Pedagogía en Lenguas Nacionales y Extranjeras de la Universidad Técnica de Ambato. Se utilizó una metodología descriptiva y correlacional, y como técnica de recolección de datos se aplicó un pre-test y pos-test de conocimientos. En este estudio de investigación participaron 73 estudiantes (36 estudiantes estuvieron en el grupo de control y 37 en el grupo experimental). Los resultados del pretest mostraron que la mayoría de los estudiantes tenían un vocabulario limitado en la lengua inglesa. Por ello, se propuso el uso de la plataforma de aprendizaje Duolingo como estrategia de gamificación para mejorar el nivel de vocabulario que los alumnos demandan. Finalmente, se aplicó un pos-test, que mostró que los alumnos pasaron de un nivel básico a uno intermedio, estableciendo la efectividad de la estrategia de gamificación propuesta (plataforma de aprendizaje Duolingo) en la adquisición de nuevo vocabulario.
\end{abstract}

\section{Abstract}

This study was conducted to establish the effectiveness of the Gamification strategy in the vocabulary acquisition in the English language in the students of the first semester at Pedagogy of National and Foreign Languages Program at Universidad Técnica de Ambato. A descriptive and correlational methodology was used, and as a data collection technique, a pretest and posttest of knowledge were applied. 73 students participated in this research study (36 students were in the control group and 37 in the experimental group). The results of the pretest showed that most of the students had a limited vocabulary in the English Language. Therefore, the use of the Duolingo learning platform was proposed as a gamification strategy to improve the level of vocabulary that students demand. Finally, a posttest was applied, which showed that the students went from a basic to intermediate level, establishing the effectiveness of the proposed gamification strategy (Duolingo learning platform) in the acquisition of new vocabulary. 


\section{Introduction}

English is considered one of the most important languages in communicating worldwide. Fluent English is one of the major challenges that students face every day. Firstly, the lack of vocabulary makes it impossible for learners to communicate accurately. For instance, in a large class, not all students participate in a discussion as they feel unsure of what to say. Secondly, learners feel frustrated and discouraged from being able to express their thoughts in the target language. According to a study conducted by Hua (2020), "If a learner has not got sufficient vocabulary, no matter how well he grasps the grammar and how idiomatic his pronunciation and tone may sound, it is hard for him or her to communicate efficiently and freely with others" (p. 427). Therefore, applying a gamification strategy allows students to broaden their vocabulary for effective communication.

Ecuador is considered one of the Latin American countries with a very low level in the English language domain. According to First (2019), Ecuador ranked 81st out of 100 countries worldwide in the English Proficiency index and it ranked $19^{\text {th }}$ out of 19 countries in Latin America becoming one of the countries with more difficulties in learning a new language. Macías \& Villafuerte (2020), state that at the end of higher studies, students must get a B1 level according to the Common European Framework of Reference (CEFR). However, this provision is not met. With this background, the Minister of Education decided to reinforce the study of language in primary school, middle school, and university.

The limited knowledge of the English language that students from the first semester of the Pedagogy of National and Foreign Language Program have, is due to the little importance that has been given to acquiring more vocabulary. The lack of vocabulary does not permit students to communicate accurately. For example, when students want to communicate about any typical situation, they have no idea about what to say or they have the idea, but they do not know the words in the English Language making them feel frustrated and unmotivated.

A study conducted by Alqahtani (2015):

Vocabulary learning is an essential part in foreign language learning as the meanings of new words are very often emphasized, whether in books or in classrooms. It is also central to language teaching and is of paramount importance to a language learner. (p.21)

In a study conducted by Kayseroglu \& Samur (2018), whose topic was "Vocabulary Learning through a Gamified Question and Answer Application Mayram" explained the application of "The quiz Game" as a gamification strategy to learn German as L2. 31 
students participated in this investigation. The aim of this research was to investigate the effect of using a gamified application, on German vocabulary to Turkish students learning German as a second foreign language. The findings show that with the help of this gamified practice tool the $97 \%$ of the learners were more enthusiastic to learn the language, especially vocabulary. The researcher applied a mixed method. It was recommended to continue doing more research applying other gamification strategies.

Similarly, a study conducted by Tamtama et al. (2020) titled "Design of English Vocabulary Mobile Apps Using Gamification: An Indonesian Case Study for Kindergarten", whose main objective was to design a mobile app using gamification as a strategy of learning. The researchers used three categories, namely numbers, pictures, and spelling. The result is a mobile-based application that can be used by children to play the introduction of English with the concept of gamification. The contribution of this study was to motivate children's willingness to learn English through other technological tools, namely gamification.

The Gamification Strategy is considered as one of the most effective strategies to improve the English learning vocabulary. Initially, many theorists agree that the application of this strategy seeks to span the vocabulary to reduce the difficulties that learners have when speaking a target language. Mchucha et al. (2017), state that students need to learn through tools or strategies that help reduce stress. In fact, young people constantly use video games, which are programmed in English, to spend their free time without noticing that they are learning the language and reducing their stress at the same time. Secondly, it permits teachers to see gamification as a help in the teaching-learning process. In summary, teachers should take advantage of the technological strength learners have to teach vocabulary.

\section{Gamification}

Gamification is defined as game-based mechanics, aesthetics, and game thinking to make students feel motivated in the learning process and make them be able to solve learning problems (Kapp, 2012). Therefore, gamification is considered a technological tool that aims at helping students find such motivation when learning, especially a language.

Huotari \& Hamari (2012), provide another relevant definition. They define gamification to offer any service in the business to support users. This definition is related to the theory of service marketing that is why this definition is applied to other contexts but teaching. The definition proposed by Chou (2015), focuses on gamification as an umbrella term to apply game-like which means to integrate designed elements or activities into a technological educational context. 
Among the less employed definitions, the one proposed by Werbach (2014) stands out gamification as "the process of making activities more game-like" (p.3). This definition focuses on the process, which means that gamification comes from a non-game context. Here it is important to emphasize the activities which can sometimes be game-like. The author's definition also states that gamification looks for creating games to support students' learning.

\section{Gamification and Games}

Considering the previous definitions, games have a crucial part when creating a gamification concept. Tekinbas and Zimmerman (2004), described the term game as an artificial conflict where players must follow rules and where there is a quantifiable result. Not only rules are present, but game elements are also part of games. It means that there are reward structures, progress tracking, rapid feedback, trial, and failure (Buckley \& Doyle, 2016). Failure, in games, has a different connotation than in real life. In real life, it is considered a negative aspect that makes learners feel demotivated. On the other hand, failure in games is considered necessary and of course a natural process to move forward.

The game design elements that were mentioned above, help the reader notice the influence of games on gamification and of course what they have in common. However, it is necessary to understand that they have a difference as well. According to Marczewski (2015), the main objective of games is to entertain students while learning.

Chou (2015), for instance, considers games as incredibly powerful tools that teachers have in their hands to make students engage and interact with technology learning at the same time. However, he also states that this powerful tool needs to be used with a teaching-learning purpose where students feel the need to learn while playing.

\section{Game design elements}

A single classification of game design elements has not been found. Under those circumstances, one of the classifications, proposed by Zichermann \& Cunninghman (2011), will be to make the readers understand the description of all game design elements. These elements were borrowed from the Mechanics-Dynamics-Aesthetics framework (MDA). It stands for three different game design elements - game mechanics, game dynamics, and game aesthetics. Together, these elements are part of the gamification experience. All these three components will be introduced here, starting with game mechanics.

\section{Game Mechanics}

According to Zichermann \& Cunningham (2011), game mechanics are rules and procedures that guide the player through the game. In other words, game mechanics are 
the way that the player interacts in the game to achieve the goal. The advantage of game mechanics is that students feel comfortable interacting through the game following rules and processes. Therefore, the seven primary game mechanics are the following: points, levels, leader boards, badges, challenges/quests, onboarding, and customization. It is important to understand that others can be applied within the gamified system. For instance, feedback, collecting, surprises, and others. All these game mechanics are part of Duolingo, a gamified application used in the experimental part of this thesis as a gamification strategy to learn vocabulary in the English language. Replay or do over are other significant examples of game mechanics, which are presented by Kapp (2012) and are also part of Duolingo.

Points are necessary for any gamified system. It means that five-points systems have different functions in a game. These points are part of the process in a game, and they cannot be taken away from the player because they track the overall progress that a player gets through the game (Zichermann \& Cunningham, 2011). These redeemable points make the player feel encouraged because they give support to the player on the different levels of a performed task. The skill points: on the other hand, are bonus sets of points that help a player to gain experience while playing.

Another game mechanic is a leader board. It has a connection with points. It gives the player a ranking system where a player can see how well he/she is doing in the game, so that the player has the opportunity to see the results to compare with others, having the opportunity to try again. This is also a way that a gamified system helps students to be motivated and of course, creating a competitive environment where students try to demonstrate their skills, learning at the same time.

The level is another game mechanic. The main purpose of levels according to Nah et al. (2014) is to show players their progress with the help of a progress bar. This game mechanic is very popular in the educational gamified tool because it permits teachers to interact with students while they are learning vocabulary. This is another way that a competitive environment is created in the classroom where students are the main agent of the game.

Moreover, there are badges, which are rewards, that symbolize the achievement of the player (Zichermann \& Cunningham, 2011). This game mechanic element permits the learner to know that his/her success is noticed and appreciated. Badges can also be used as a traditional point-based grading system. Obtaining badges is a way to make learners feel motivated to further their learning and span their vocabulary in the English Language accurately.

The fourth game mechanism is known as challenges or quests. In other words, it refers to a hunt for a specific outcome where players receive directions within the game. This 
element makes students more competitive while learning. It also makes students gain new skills and progress in different areas of learning.

The fifth game mechanism is customization. It refers to the direct impact the player gets in a game. In other words, it means how the player controls the gameplay. This element makes students become special snowflakes because it gives the player an additional flavor while playing a game. Customization permits players to create something unique in a gaming world.

The last core game mechanism presented in Zichermann \& Cunningham (2011), is onboarding. Onboarding refers to the first experience a new player feels so that he/she can decide when coming back again and again or just decide to close de game immediately and just eliminate it. In the teaching-learning process, this is crucial because here the student decides if he/she wants to learn with the game you as a teacher chooses for them. So, the goal here is to accommodate your user and get them to use your product. It is necessary to apply games that make students feel interested.

\section{Game Dynamics}

Game Dynamics are not so important for gamification experience, but it is necessary to be mentioned since they are part of the MDA Frameworks. These components can be described as the outcome that the player must achieve in a game. There are three elements withing Game Dynamics being these constraints, emotions, and narrative. These elements create an aesthetic experience (emotional reaction) in students, making them experience new learning alternatives where the main learning tool is the game.

\section{Game aesthetics}

Game aesthetics are another element of MDA Frameworks. They focus on aesthetic qualities where emotions are implicated. These elements permit students to find the necessary motivation to interact with the game and with the content of learning at the same time. In other words, game aesthetics refer to how the game makes the player feel; it means the emotional responses toward the game.

\section{Gamification in Education}

Nowadays, Gamification is increasing in any context, specifically in education. A study conducted by Dicheva \& Dichev (2015), states that gamification is the "introduction of game elements and grateful experiences in the design of learning processes" (p.1). When gamification is included in the educational context, many opportunities arrive in the teaching-learning process. One is these opportunities, as teachers, is to see how gamification strategies motivate students to learn a language while playing. Therefore, gamification has become an important tool in the educational field for language teachers. 
To get a better idea of how gamification is applied in the educational context, two examples of successfully gamified programs are presented. Firstly, gamification strategies can be applied not only on whole courses but individual subjects, being English one of these, specifically vocabulary. Class Dojo is an interactive, online, classroom management platform, whose main purpose is to make students participate interactively through the game. The platform contains many game elements such as avatars, giving points to students for various kinds of positive and negative behavior, a progress bar, or lovely illustrations (Silver-Bonito, 2014). GoalBook, Coursera, or CourseHero are also similar gamified applications. They focus on general classrooms where gamification elements are present. These programs provide students with studying materials where students receive some rewards using badges for their progress (Chou, 2015).

There is another group of gamified tools which are used for educational purposes. These tools are focused on individual subjects. One example of these tools is explained to give the reader a clear idea of how these gamified tools work. KnowRe is an online adaptive Math learning program. This program uses a lot of game elements such as personalization, reward-system, rapid feedback, there are several game mechanics - points, progress bars - and highly-developed game aesthetics. This program is well-known for its influence on students' motivation (Dicheva \& Dichev, 2017).

Gamification in education is considered a new and novel experience to be applied in the teaching-learning process; however, many studies have been published on this subject of gamification. These studies show a big picture of this interesting strategy. They focus on the importance of applying gamification to motivate and make students feel comfortable learning vocabulary in the English Language.

\section{Gamification and vocabulary}

Vocabulary knowledge is considered as the root when learning a language because it helps people to have a mental dictionary where words come out without too much effort when communicating any idea. It provides an in-depth understanding when reading and writing. However, being vocabulary a necessary tool to communicate, teachers do not give the importance it requires. Consequently, students have such a limitation to express their ideas because of the lack of vocabulary. Even though technology has permitted us to find new and novel ways to learn vocabulary through gamified strategies. These gamification strategies make the teaching and learning process more dynamic because digital games have become an important part of learners' lives (Krokfors et al., 2014, p.13).

Although gamification is not new in the educational field, the application of digital games in the teaching-learning process is new. Despite this, many researchers have seen the need to conduct many experiments to demonstrate if gamification has a positive or negative 
effect in learning a language, specifically vocabulary, in any target language. Vesterinen \& Mylläri (2014), mention that digital games facilitate teachers to teach outside the classroom. It means that students could learn vocabulary without the need to be in a physical classroom. They could use this gamification strategy in any place they are. It becomes a formal and informal teaching learning process for both teachers and students (Krokfors et al., 2014, p.67). Also, Kapp (2012) mentions that "it is not easy to create a game that is both fun to play and instructional" (p.14).

\section{Duolingo}

Duolingo is an e-learning platform whose main purpose is to help people to learn a language. This application has a desktop version that contains 22 languages. This platform is considered as one of the strategies within gamification. Duolingo's platform allows educators to create groups for each class. Most important is that educators can monitor students' progress to give feedback when they consider it necessary.

Munday (2015), states the following:

This generates a link, which can be sent to students so that they can join the group. In the dashboard, the teacher can monitor students' progress in several ways. The dashboard shows the time the student logged in, the lesson or practice he/she completed and the XP he/she obtained. A weekly report is sent by email, which includes all the work students have done during that time. In addition, there is now a dedicated area in the Discussion Forums just for educators' concerns and ideas. (p.88)

Duolingo is considered one of the most popular gamification strategies. It has had a big impact in the educational field due to the positive results it has obtained, especially when it is used as a teaching strategy to teach a target language. The popularity of this platform has attracted governments' attention in Latin America. A clear example of this is what Orellana (as cited in Garcia et al., 2017), mentioned that in 2014 Guatemalan Government reached an agreement with Duolingo to be included in the curriculum of 97 public schools. Another important piece of data is the one provided by the Ministry of Labour (as cited in Garcia et al., 2017) "the Colombian government presents a project whose main purpose is to include Duolingo as a strategy to provide high-quality English education for free with the possibility to obtain a free language certificate" (p.43). As it can be seen, Duolingo is not only an app or a platform, but also a potential strategy to teach English. Thus, even teachers in other countries are being trained in the pedagogical use of Duolingo.

This platform mostly focuses on translations to help students improve grammar and vocabulary. That is why the researcher considered using this platform as a proposal to 
improve the vocabulary in the English language. In addition, Duolingo platform facilitates students to develop pronunciation while learning vocabulary in a target language. The important aspect to mention here is that this platform uses a wide range of games elements to simplify the learning. Duolingo has two types of points: XP and redeemable points (lingots). There are also the badges; these are given to students as a price for their constant effort in practicing the different activities. Also, they are given to learners for signing regularly. Another advantage that Duolingo provides students is that they have the opportunity to interact and practice the language with people around the world.

\section{Duolingo in educational field}

Duolingo is a motivational learning platform, which means that students are exposed to entertainment while learning. All the skills have a systematic structure that facilitates students' learning. Each skill has a level of complexity that students must achieve while they practice (Duy et al., 2017).

Several studies have shown statistically that the application of this platform in the teaching-learning process has had satisfactory results. The motivation that students feel when learning a foreign language through this platform has allowed them to lose that fear. This platform seeks to facilitate the student's learning, making it more dynamic and interactive (Musa \& Mohamad, 2017). The use of the Duolingo platform allows learning different topics according to the student's needs. As the student develops each of the activities, he/she learns new vocabulary. This great advantage that this platform offers makes the student feel the necessary confidence to be able to take the next step which is to communicate in the English language. It is necessary to mention that besides learning a lot of vocabulary, the pronunciation of each word is also learned. This facilitates correct pronunciation especially of unfamiliar words (Castro et al., 2016).

\section{Methodology}

This study applied quasi-experimental research with a control and experimental group. Seventy-three students of first semester A and B of Pedagogy of National and Foreign Language Program in Universidad Técnica de Ambato participated. They were asked to practice Duolingo as a gamification strategy for thirty days. Learners' vocabulary mastery was measured by a pretest before they started using the platform. Two instruments were used in this study. They are a test and a questionnaire to collect the data needed. A test was used as the instrument of the study to know the students' achievement in vocabulary. This test was taken from Cambridge exams (KET). The pre-test was done to measure the students' achievement in English vocabulary while the post-test was done to measure the improvement in students' vocabulary after the intervention. The questionnaire, which contained five questions, was used by the researcher to identify, and knew the students' 
perception towards the use of Gamification strategy, specifically Duolingo platform in learning English vocabulary. The test contains 100 questions focused on vocabulary and language which was divided into three categories: nouns, adjectives, and verbs. This Cambridge test (KET) was applied to check students' vocabulary knowledge. The evaluation criteria that the researcher used in this study was focused on broad, accurate and effective use of nouns, adjectives, and verbs.

\section{Results}

It was essential to check the data in the pre-test and post-test to verify that all the information was accurate and contributed to this study. Tabulation was based on the research topic to get relevant information. It was relevant to see the frequency of the results to represent in tables. The tabulation was done manually, so that the information required to be checked carefully.

Table 1

The score of pre-test and post-test in control class

\begin{tabular}{ccc}
\hline Students & Pre-Test & Post-Test \\
\hline Student 1 & 56 & 76 \\
Student 2 & 36 & 64 \\
Student 3 & 52 & 76 \\
Student 4 & 76 & 88 \\
Student 5 & 32 & 68 \\
Student 6 & 56 & 76 \\
Student 7 & 36 & 40 \\
Student 8 & 60 & 72 \\
Student 9 & 48 & 76 \\
Student 10 & 36 & 60 \\
Student 11 & 24 & 72 \\
Student 12 & 20 & 52 \\
Student 13 & 24 & 44 \\
Student 14 & 56 & 76 \\
Student 15 & 64 & 76 \\
Student 16 & 60 & 80 \\
Student 17 & 40 & 64 \\
\hline
\end{tabular}




\section{Table 1}

The score of pre-test and post-test in control class (continuation)

\begin{tabular}{|c|c|c|}
\hline Students & Pre-Test & Post-Test \\
\hline Student 18 & 28 & 48 \\
\hline Student 19 & 52 & 60 \\
\hline Student 20 & 56 & 76 \\
\hline Student 21 & 76 & 88 \\
\hline Student 22 & 52 & 80 \\
\hline Student 23 & 32 & 68 \\
\hline Student 24 & 92 & 100 \\
\hline Student 25 & 88 & 92 \\
\hline Student 26 & 28 & 52 \\
\hline Student 27 & 48 & 72 \\
\hline Student 28 & 72 & 88 \\
\hline Student 29 & 52 & 60 \\
\hline Student 30 & 24 & 60 \\
\hline Student 31 & 60 & 88 \\
\hline Student 32 & 28 & 44 \\
\hline Student 33 & 80 & 80 \\
\hline Student 34 & 80 & 80 \\
\hline Student 35 & 40 & 80 \\
\hline Student 36 & 20 & 52 \\
\hline Total Score & 1784 & 2528 \\
\hline Mean Score & 49.56 & 70.22 \\
\hline
\end{tabular}

\section{Source: Jordan (2021)}

The pre-test and post-test that were given to the 36 students from the control group measured the students' vocabulary knowledge without the application of Duolingo. The researcher did not apply any gamification strategy in this group. Based on the pre-test score, it can be said that the mean score of the control group was 49.56. The lowest score in the pre-test was 20 and the highest score was 92.

\section{Table 2}

Pre-test and Post-Test results from the Experimental group

\begin{tabular}{ccc}
\hline Students & Pre-Test & Post-Test \\
\hline Student 1 & 36 & 80 \\
Student 2 & 60 & 96 \\
Student 3 & 52 & 68 \\
Student 4 & 68 & 84 \\
\hline
\end{tabular}




\section{Table 2}

Pre-test and Post-Test results from the Experimental group (continuation)

\begin{tabular}{|c|c|c|}
\hline Students & Pre-Test & Post-Test \\
\hline Student 5 & 80 & 88 \\
\hline Student 6 & 52 & 96 \\
\hline Student 7 & 64 & 100 \\
\hline Student 8 & 68 & 80 \\
\hline Student 9 & 60 & 76 \\
\hline Student 10 & 56 & 64 \\
\hline Student 11 & 44 & 88 \\
\hline Student 12 & 48 & 84 \\
\hline Student 13 & 72 & 76 \\
\hline Student 14 & 48 & 64 \\
\hline Student 15 & 40 & 64 \\
\hline Student 16 & 28 & 76 \\
\hline Student 17 & 56 & 76 \\
\hline Student 18 & 36 & 64 \\
\hline Student 19 & 76 & 84 \\
\hline Student 20 & 52 & 64 \\
\hline Student 21 & 32 & 92 \\
\hline Student 22 & 56 & 96 \\
\hline Student 23 & 36 & 88 \\
\hline Student 24 & 60 & 72 \\
\hline Student 25 & 60 & 100 \\
\hline Student 26 & 52 & 92 \\
\hline Student 27 & 48 & 68 \\
\hline Student 28 & 68 & 96 \\
\hline Student 29 & 52 & 72 \\
\hline Student 30 & 52 & 80 \\
\hline Student 31 & 80 & 100 \\
\hline Student 32 & 44 & 80 \\
\hline Student 33 & 60 & 72 \\
\hline Student 34 & 100 & 100 \\
\hline Student 35 & 92 & 96 \\
\hline Student 36 & 92 & 100 \\
\hline Student 37 & 40 & 76 \\
\hline Total Score & 2120 & 3052 \\
\hline Mean Score & 57,3 & 82,49 \\
\hline
\end{tabular}

Source: Jordan (2021) 
37 students participated in the experimental group. They were from the first semester A. The pre-test was done to measure the students' vocabulary knowledge before the application of Duolingo as a gamification strategy. Based on the pre-test score, it can be said that the mean score of the experimental class was 57.30. The lowest score in the pretest was 28 and the highest score was 100. After the data was measured from the pre-test, Duolingo application was used by this group. After concluding the intervention, the posttest was applied to measure whether Duolingo influences students' achievement in vocabulary by distinguishing both pre-test and post-test score. From the post-test, the mean score of the students in the experimental group increased to be 82.49 and the range of the mean score from pre-test to post-test was 25.19.

General results from the pre-test and post-test from the control and experimental groups

Table 3

\section{General results}

General results from the pre-test and post-test applied to control and experimental group

\begin{tabular}{lc}
\hline Pre-test control group & 49,56 \\
Pre-test experimental group & 57,3 \\
Post-Test control group & 70,22 \\
Post-test experimental group & 82,49
\end{tabular}

Source: Jordan (2021)

This table shows that the mean score of this experimental group in the pre-test was 57.30; meanwhile, on the control group the mean score was 49.56. The results obtained in the post-test confirmed that there is a significant difference $(12,27)$ between the results gotten from the control group and the experimental group, which means that the application of Duolingo has a positive impact on students 'learning, specifically when they learn vocabulary.

\section{Conclusions}

Based on the research, which had been conducted at Pedagogy of National and Foreign languages Program, in the first semester " $A$ " as the experimental group and "B" as the control group, this research aimed to implement Gamification Strategy in the English language learning vocabulary. Duolingo platform was the gamify strategy that the researcher focused on obtaining the following conclusions: 
- Most of the studies in Gamification strategy focused on the effectiveness of using the Duolingo platform or application as a gamify teaching strategy. The results of these studies showed that this platform facilitates the acquisition of new vocabulary in the English language. Additionally, most of the authors stated that motivation has been a huge factor within this platform because it has permitted students to explore new ways of learning through the games.

- This study showed that the Duolingo platform facilitates the learning of vocabulary in the English language due to its ease of use and the variety of activities it contains. It also attracted the attention of the students, to whom the experiment was applied, since its design resembles a game platform where students must complete all the lessons to level up by obtaining points and gaining positions.

- The results obtained in the pre-test and post-test confirm the hypothesis stated at the beginning of this research. The Duolingo platform is effective in the development of English vocabulary. This data could be corroborated with the application of the questionnaire where we sought to analyze the opinions of the students towards the use of this platform, who mentioned feeling motivated during the completion of the assigned lessons.

\section{Bibliographical References}

Alqahtani, M. (2015). The importance of vocabulary in language learning and how to be taught. International Journal of Teaching and Education, III (3), 21-34. https://doi.org/10.20472/te.2015.3.3.002

Buckley, P., \& Doyle, E. (2016). Gamification and student motivation. Interactive Learning 24(6), $1162-1175$. https://doi.org/10.1080/10494820.2014.964263

Castro, Da Hora, \& Pereira, T. (2016). The effect of game-based learning on vocabulary acquisition for middle school English language learners. ProQuest Dissertations and Theses, 103. https://bit.ly/3JVv0fA

Chou, P. (2015). A Review of Data Analysis for Gamification: Challenges, Motivations, Recommendations and Methodological Aspects. Turkish Journal of Computer and Mathematics Education (TURCOMAT), 12(3), 928-960. https://doi.org/10.17762/turcomat.v12i3.828

Dicheva, D., \& Dichev, C. (2015, October). Gamification in education: Where are we in 2015? [Online]. Paper presented at the E-Learn Conference 2015 - World Conference on E-Learning, Kona, Hawaii. Retrieved from 
http://www.wssu.edu/profile/dept/cs/dichevc/documents/gamification-educationwhere-are2015.pdf

Dicheva, D., \& Dichev, C. (2017). Gamifying education: What is known, what is believed and what remains uncertain: A critical review [Online]. International Journal of Educational Technology in Higher Education, 14(9), 1-36. Retrieved from https://link.springer.com/article/10.1186/s41239-017-0042-5

Duy, P., Long, M., \& Hiroyuki, H. (2017). A mobile gamification learning system for improving the learning motivation and achievements. Journal of Computer Assisted Learning, 31(3), 268-286.

First, E. (2019). The world's largest ranking of countries and regions by English skills.

Retrieved on July 18, 2019.

Garcia, G., Garcia, J., \& Questier, F. (2017). Governmental partnerships for language learning: A commercial language platform for young workers in Colombia. The EuroCALL Review, 25(2), 42. https://doi.org/10.4995/eurocall.2017.8620

Hua, D. (2020). An Analysis of Winning Streak's Effects in Language Course of "Duolingo." Asia-Pacific Journal of Information Technology \& Multimedia, 06(02), 23-29. https://doi.org/10.17576/apjitm-2017-0602-03

Huotari, X., \& Hamari, T. (2012). Game-based learning platform and its effects on present tense mastery: Evidence from an ESL classroom. International Journal of Learning, Teaching and Educational Research, 19(5), 13-26. https://doi.org/10.26803/ijlter.19.5.2

Jordan, Buenaño, C. R. (2021). Gamification strategy and the English learning vocabulary. (Tesis de Maestría). Pontificia Universidad Católica del Ecuador. Sede Ambato. https://repositorio.pucesa.edu.ec/bitstream/123456789/3319/1/77474.pdf

Kapp, K. (2012). The Gamification of Learning and Instruction: Game-Based Methods and Strategies for Training and Education. San Francisco: John Wiley \& Sons.

Kayseroglu, M. A., \& Samur, Y. (2018). Journal of learning and teaching in digital age. Journal of Learning and Teaching in Digital Age (JOLTIDA), 3(2), 27-41. http://joltida.org/index.php/joltida/article/view/60/129

Krokfors, M., Kangas, S., \& Kopisto, M. (2014). Journal of learning and teaching in digital age. Journal of Learning and Teaching in Digital Age (JOLTIDA), 3(2), $27-$ 41. http://joltida.org/index.php/joltida/article/view/60/129

Macías, Y. y Villafuerte, J. (2020). Teaching English Language in Ecuador: A Review 
from the Inclusive Educational Approach. Journal of Arts \& Humanities, 9(2), 7590. http://doi.org/10.18533/journal.v9i2.1854

Marczewski, Z. (2015). Receptive Vocabulary Knowledge or Productive Vocabulary Knowledge in Writing Skill, Which One Important? 6(11), 261-271. https://doi.org/10.6007/IJARBSS/v6-i11/2395

Mchucha, Ismail, \&Tibok. (2017). Gamified EFL instruction: An overview of the most recent research trends. CEUR Workshop Proceedings, 2145, 7-12.

Munday, P. (2015). the Case for Using Duolingo as Part of the Language Classroom Experience. RIED. Revista Iberoamericana de Educación a Distancia, 19(1). https://doi.org/10.5944/ried.19.1.14581

Musa, T., \& Mohamad, P. (2017). The Effects of Digital Game-based Learning on Primary School Students in the English Vocabulary Achievement and Acceptance. Innovative Teaching and Learning Journal, 1(1), 61-74. http://web2.fp.utm.my/itlj/index.php/itlj/article/viewFile/14/11

Nah F.FH., Zeng Q., Telaprolu V.R., Ayyappa A.P., Eschenbrenner B. (2014) Gamification of Education: A Review of Literature. In: Nah F.FH. (eds) HCI in Business. HCIB 2014. Lecture Notes in Computer Science, vol 8527. Springer, Cham. https://doi.org/10.1007/978-3-319-07293-7_39

Silver-Bonito, T. (2014). Video Games as Motivators of English Vocabulary Acquisition and Reading. 453(Inusharts 2019), 22-27.

Tamtama, G. I. W., Suryanto, P., \& Suyoto. (2020). Design of English vocabulary mobile apps using gamification: An Indonesian case study for kindergarten. International Journal of Engineering Pedagogy, 10(1), 105-162. https://doi.org/10.3991/ijep.v10i1.11551

Tekinbas, M., \& Zimmerman, R. (2004). Design of English vocabulary mobile apps using gamification: An Indonesian case study for kindergarten. International Journal of Engineering Pedagogy, 10(1), 105-162. https://doi.org/10.3991/ijep.v10i1.11551

Vesterinen, W., \& Mylläri, A. (2014). An investigation of the effectiveness of English language apps for EFL vocabulary building. VI(I), 1083-1102.

Werbach, L. (2014). Adquisición de Nuevo Vocabulario a través de Guadalingo: Un Caso Experimental Máster Universitario en Lenguas y Tecnología Estudiante: Lulu Wang Supervisor: Ricardo Casañ Pitarch.

Zichermann, M., \& Cunninghman, T. (2011). Constructivist Learning, Vocabulary 


\section{DDigital}

Learning Strategies and Motivational Theories for English Vocabulary Acquisition Tool Using Cloud Computing. International Journal of Academic Research in Business and Social Sciences, 9(13). https://doi.org/10.6007/ijarbss/v9-i13/6485

\section{\Ciencia}


El artículo que se publica es de exclusiva responsabilidad de los autores y no necesariamente reflejan el pensamiento de la Revista Conciencia Digital.

\section{Liencia}

El artículo queda en propiedad de la revista y, por tanto, su publicación parcial y/o total en otro medio tiene que ser autorizado por el director de la Revista Conciencia Digital.
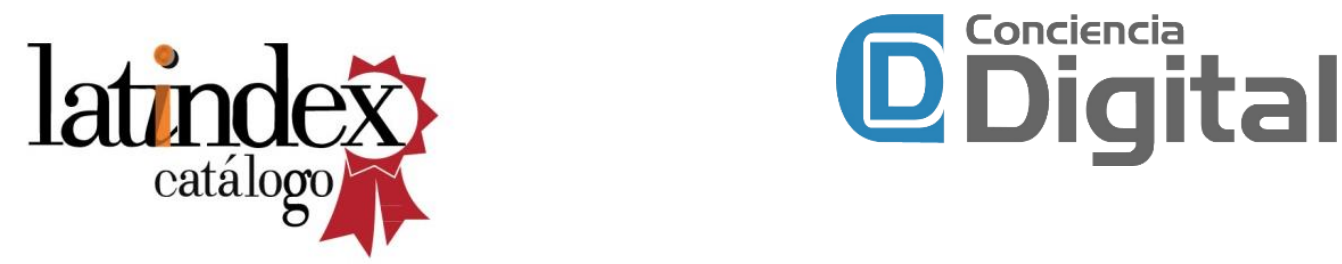

Indexaciones

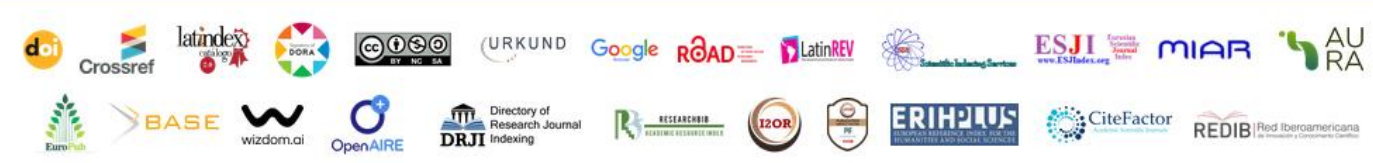

